\title{
Freshwater fishes of West Kabylia, Algeria
}

\author{
Lyas Baikeche ${ }^{1, *}$, Abdelkader Lounaci', Matthew Ford², Dhya Lounaci-Daoudi' \& Jörg Freyhof ${ }^{2}$ \\ ${ }^{1}$ Laboratory of Natural Resources, Faculty of Biological Sciences and Agricultural Sciences, Mouloud Mammeri \\ University, BP 15000 Tizou Ouzou, Algeria \\ ${ }^{2}$ Museum für Naturkunde, Leibniz Institute for Evolution and Biodiversity Science, 10115 Berlin, Germany \\ *Corresponding author, e-mail: lyas.baikeche@ummto.dz
}

\begin{abstract}
In this work, the diversity of freshwater fishes from western Kabylia (northern Algeria) was examined and a total of 18 species were identified, including seven native and 11 non-native species. Only Luciobarbus setivimensis, Salaria fluviatilis, Tropidophoxinellus callensis are exclusive native freshwater inhabitants with the remainder euryhaline migrants or temporary residents. The highest species richness was recorded in the Oued-Aïssi drainage where 13 species were recorded, followed by the Oued-Bougdourra with seven species and the OuedBoubhir with six species. The most widespread and abundant native species is Luciobarbus setivimensis, which was found at 20 sites, while non-native Carassius auratus and Pseudorasbora parva were recorded at 15 and 14 sites, respectively.
\end{abstract}

KEY WORDS Distribution; Freshwater fish; Inventory; Sebaou; West Kabylia.

Received 23.10.2021; accepted 05.12.2021; published online 30.12.2021

\section{INTRODUCTION}

Kabylia is a part of northern Algeria and it has a relatively wet climate and a great variety of landscapes reflected in diverse and species-rich animals and plants communities (Jeannel, 1956; Roberts, 1975; Rosenbaum et al, 2002; Lévêque \& Paugy, 2006). However, the freshwater fish diversity and the distribution of species remain incompletely known.

Boulenger (1911) and Pellegrin (1921) published the first catalogs of fishes from northern Africa, including Algeria. Seurat (1922, 1930), Dieuzeide (1927, 1932), Dieuzeide \& Champagne (1950), Dieuzeide \& Roland (1951), Almaça (1969), Bouhaddad (1993), Doadrio (1994) and Bouhadadad \& Asselah (1998), published subsequent studies which referred to the fishes of Algeria.

More recently, Zouakh et al. (2004) studied the ichthyofauna of the Hoggar and Tassili highlands, Chaoui et al. (2006) surveyed Lake Mellah,
Blanco et al. (2006) described a new species of Apricaphanius from the Saoura Valley, and Bacha \& Amara (2007) provided an updated inventory of fish species inhabiting the Soummam River system. A national overview of all native and alien species was published by Kara (2011), while Chaibi (2014) surveyed the Aurès and northern Sahara regions, Djezzar (2015) focussed on artificial reservoirs in the upper Cheliff River, and Brahimi et al. (2017); Brahimi et al. (2018) described new species in the genus Luciobarbus.

To date, only Penczak \& Molinski (1984) and Lounaci-Daoudi et al. (2016) have provided data on the freshwater fishes of West Kabylia. Ford et al. (2020) provided an overview of the known distribution of freshwater fishes across the entire Maghreb region, and called on the ichthyological community to fill knowledge gaps and increase the availability of open access range data in order to improve conservation management efforts.

The present work provides an update on the distribution of freshwater fish species in the West 
Kabylia region. The main objectives of this study were (1) to establish a more complete and up-todate list of freshwater fishes in order to provide baseline data for future management or monitoring programs, and (2) to rectify the taxonomic uncertainty created by previous studies. In addition to sharing occurrence data, this study also integrates more descriptive distribution data to assist in the development of global observation databases based on field records.

\section{MATERIAL AND METHODS}

\section{Study area}

Fieldwork was carried out in West Kabylia, a geographical region in the central Tell Atlas Mountains of northern Algeria (Fig. 1). The region covers approximately $25,000 \mathrm{~km}^{2}$ extending eastwards from Thénia to Béjaïa $\left(3.3-5.0^{\circ} \mathrm{E}\right)$, and northwards from the Djurdjura mountain range to the Mediterranean Sea $\left(36.3-36.9^{\circ} \mathrm{N}\right)$. The region experiences a typical Mediterranean climate with hot, dry summers and cool, mild winters, and annual precipitation of $800-1200 \mathrm{~mm}$ depending on altitude (Lounaci \& Vinçon, 2005)

The Sebaou is the major river drainage in the region, occupying an area of roughly $3,000 \mathrm{~km}^{2}$. Its sources are located on the north face of the Djurdjura massif (2308 $\mathrm{m}$ AMSL) and the southern slopes of the coastal range ( $800 \mathrm{~m}$ AMSL), from where it flows for around 110 kilometers before discharging into the Mediterranean Sea at Takdemt ( $36^{\circ} 54^{\prime} \mathrm{N}$ $3^{\circ} 51^{\prime} \mathrm{E}$ ), near the town of Dellys (Lounaci, 2005).

The three main tributaries of the Sebaou are the Boubhir, Aïssi, and Bougdoura rivers. The Taksebt, Draa El Mizan, Ain Zaouia, and Djebla dams were constructed within the drainage between the late 1960s and 2002 (Lounaci, 2005). The first-order Sidi Khlifa and Ath Chafaa rivers, which drain the northern face of the coastal mountain range, and the Cap-Djinet man-made reservoir were also included within the framework of the study but do not share hydrographic connections with the Sebaou.

\section{Sampling and mapping}

Fishes were sampled from April to July in both 2018 and 2019, and occasionally outside these periods. Sampling sites were selected to represent

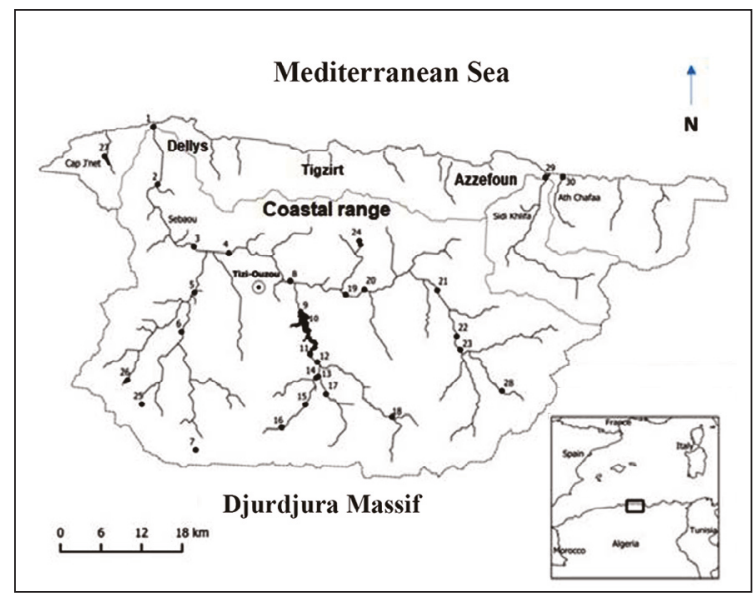

Figure 1. Map of the West Kabylia region indicating all sites sampled during this study.

a wide range of available habitats within the study area. Wadeable river stretches and shorelines of reservoirs were sampled using a variable current electro-fishing backpack with attached dip net, operated by two practitioners with current: AC (3 phases); Power: $1.5 \mathrm{KVA}$; Voltage: 230/400 V; Current: 5.2/2.8 A; Frequency: $670 \mathrm{~Hz}$. At each of these sampling sites, fishing was carried out along a stretch of 100 meters and up to 3 meters from the edge of the bank.

Fishes were mostly identified in situ before being released alive, with some individuals preserved in $70 \%$ ethanol for further analyses. In rivers and reservoirs, $100 \times 10$ meters single or $50 \times 1.5$-meters trammel drift gill nets with various mesh sizes were installed and left in place for 24 hours, and some individuals were collected using rod and line. Identification was based on keys provided by Azeroual (2003), Kottelat \& Freyhof (2007), and Brahimi et al. (2018). The sampling sites were visualized on a regional-scale map using the open-source Geographic Information System QGIS version 3.4 (QGIS, 2019), with each site displayed as an individual point. Inland waters were derived from $\mathrm{Hy}-$ droSHEDS (Lehner et al., 2008) while some lakes were digitized manually using Google Earth Pro.

\section{RESULTS}

During this study, 30 sites were surveyed and 18 species were identified. Among these, seven species were native and 11 non-native to the study area. Only three native species are both resident 


\begin{tabular}{|c|c|c|c|c|c|c|c|c|c|c|c|c|c|c|c|c|c|c|c|c|c|c|c|c|c|c|c|c|c|c|}
\hline & \multirow{2}{*}{\multicolumn{2}{|c|}{\begin{tabular}{|c|}
$\begin{array}{c}\text { Lower } \\
\text { Sebaou }\end{array}$ \\
\\
\\
\multirow{2}{*}{} \\
\end{tabular}}} & \multicolumn{4}{|c|}{ Middel Sebaou } & \multirow{2}{*}{\multicolumn{3}{|c|}{$\begin{array}{r}\text { Upper- } \\
\text { Sebaou } \\
\\
\end{array}$}} & \multicolumn{5}{|c|}{ Bougdoura } & \multicolumn{10}{|c|}{ Aissi } & \multicolumn{3}{|c|}{ Boubhir } & \multirow{2}{*}{\multicolumn{2}{|c|}{ 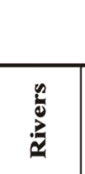 }} & \multirow{3}{*}{ 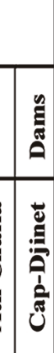 } \\
\hline & & & & 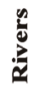 & & 气ี & & & & & 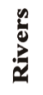 & & & हू & & 气 & & & & & $\frac{n}{2}$ & & & & & 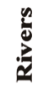 & & & & \\
\hline & 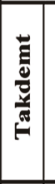 & 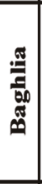 & 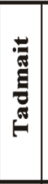 & $\stackrel{\ddot{a}}{\hat{\theta}}$ & 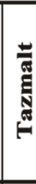 & 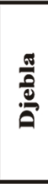 & 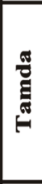 & 苞 & 吾 & 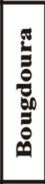 & 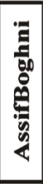 & 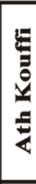 & $\begin{array}{l}N \\
\text { N }\end{array}$ & 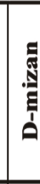 & 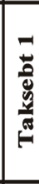 & 告 & 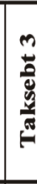 & 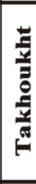 & 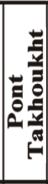 & 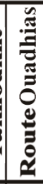 & & 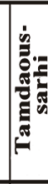 & 恖 & 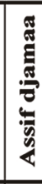 & 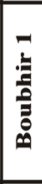 & 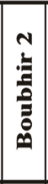 & & 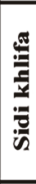 & 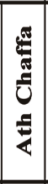 & \\
\hline $\begin{array}{l}\text { Species / } \\
\text { Map codes }\end{array}$ & 1 & 2 & 3 & 4 & 8 & 24 & 19 & 20 & 21 & 5 & 6 & 7 & 25 & 26 & 9 & 10 & 11 & 12 & 13 & 14 & 15 & 16 & 17 & 18 & 22 & 23 & 28 & 29 & 30 & 27 \\
\hline Petromyzon marinus & & & & & & & & & & & & & & & & & & $*$ & & & & & & & & & & & & \\
\hline Anguilla anguilla & * & $*$ & ${ }^{*}$ & $*$ & & * & * & * & $*$ & * & * & $*$ & * & * & & $*$ & & & & & & & & & & * & & $*$ & & \\
\hline Alosa algeriensis & * & & & * & & & & & $*$ & & & & & & & & & & & & & & & & * & & & & & \\
\hline Cyprinus carpio & & & $*$ & $*$ & $*$ & * & * & $*$ & & * & $*$ & & $*$ & * & $*$ & $*$ & & & & & & & & & & $*$ & & & & \\
\hline $\begin{array}{l}\text { Luciobarbus } \\
\text { setivimensis }\end{array}$ & & & & & * & * & & * & * & 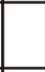 & * & * & * & * & & & * & * & * & * & * & * & * & * & $*$ & * & * & * & & $*$ \\
\hline Carassius auratus & & * & * & * & & * & & * & $*$ & * & * & & & & * & * & * & * & * & & & & & & $*$ & * & & & & \\
\hline $\begin{array}{l}\text { Ctenopharyngodon } \\
\text { idella }\end{array}$ & & & & & & & & & & & & & * & & & * & & & & & & & & & & & & & & \\
\hline $\begin{array}{l}\text { Hypophthalmichthys } \\
\text { molitrix }\end{array}$ & & & & & & & & & & & & & & & $*$ & * & & & & & & & & & & & & & & \\
\hline $\begin{array}{l}\text { Hypophthalmichthys } \\
\text { nobilis }\end{array}$ & & & & & & & & & & & & & & & * & * & & & & & & & & & & & & & & \\
\hline Pseudorasbora parva & & $*$ & $*$ & $*$ & & & & & $*$ & $*$ & $*$ & & & & $*$ & * & $*$ & $*$ & * & $*$ & & & * & & & $*$ & & & & \\
\hline Rutilus rutilus & & & & & & & & & & & & & & & & $*$ & $*$ & $*$ & & & & & & & & & & & & $*$ \\
\hline $\begin{array}{l}\text { Tropidophoxinellus } \\
\text { callensis }\end{array}$ & & & & & & & & & & & & & & & & * & & * & & & & & & & & & & & & * \\
\hline Atherina boyeri & & & & & & & & & & & & & & & & $*$ & & & & & & & & & & & & & & $*$ \\
\hline Gambusia holbrooki & & & & & & & & & & & & & & & & & & & & & & & & & & & & & & $*$ \\
\hline Mugil cephalus & * & & & & & & & & & & & & & & & & & & & & & & & & & & & * & & * \\
\hline Salaria fluviatilis & & & & & & & & & & & & & & & & & & & & & & & & & & & & & * & \\
\hline Micropteris salmoides & & & & & & & & & & & & & & * & & & & & & & & & & & & & & & & $*$ \\
\hline Sander lucioperca & & & & & & & & & & & & & * & * & $*$ & * & * & * & & & & & & & & & & & & $*$ \\
\hline
\end{tabular}

Table 1. Fish species distribution in West Kabylia; * = presence.

and exclusively freshwater inhabitants (Luciobarbus setivimensis, Salaria fluviatilis, and Tropidophoxinellus callensis), while the others were euryhaline migrants or temporary residents. The greatest species richness was recorded in the Aïssi River, where 13 species were recorded, followed by the Bougdoura River with eight species and the Boubhir River with six species (Table 1).

Alosa algeriensis is reported for the first time in West Kabylia. Luciobarbus setivimensis is the most widespread and abundant native species, being present at 20 sites, while the non-native species $\mathrm{Ca}$ rassius auratus and Pseudorasbora parva were recorded at 15 and 14 sites, respectively. The known ranges of the native Salaria fluviatilis, Tropidophoxinellus callensis, and non-native Pseudorasbora parva and Gambusia holbrooki in the study area were extended as a result of the surveys.

Quantitatively, the surveys collected 1951 individuals. Relative abundance is calculated as the percentage of individuals of the species relative to the total individuals captured at all sites. The relative abundance and frequency of occurrence of all species at all sites are presented in Fig. 2.

The known global ranges for the two anadromous migrant species (Alosa algeriensis, Petromyzon marinus), and the two native freshwater species (Salaria fluviatilis and Tropidophoxinellus callensis) were extended, based on the results of this study.

Six out of eight alien species were voluntarily (Hypophthalmichthys nobilis, Hypophthalmichthys molitrix, Gambusia holbrooki, Ctenopharyngodon idella, Micropterus salmoides, Sander lucioperca) or accidentally (Rutilus rutilus and Atherina boyeri) 


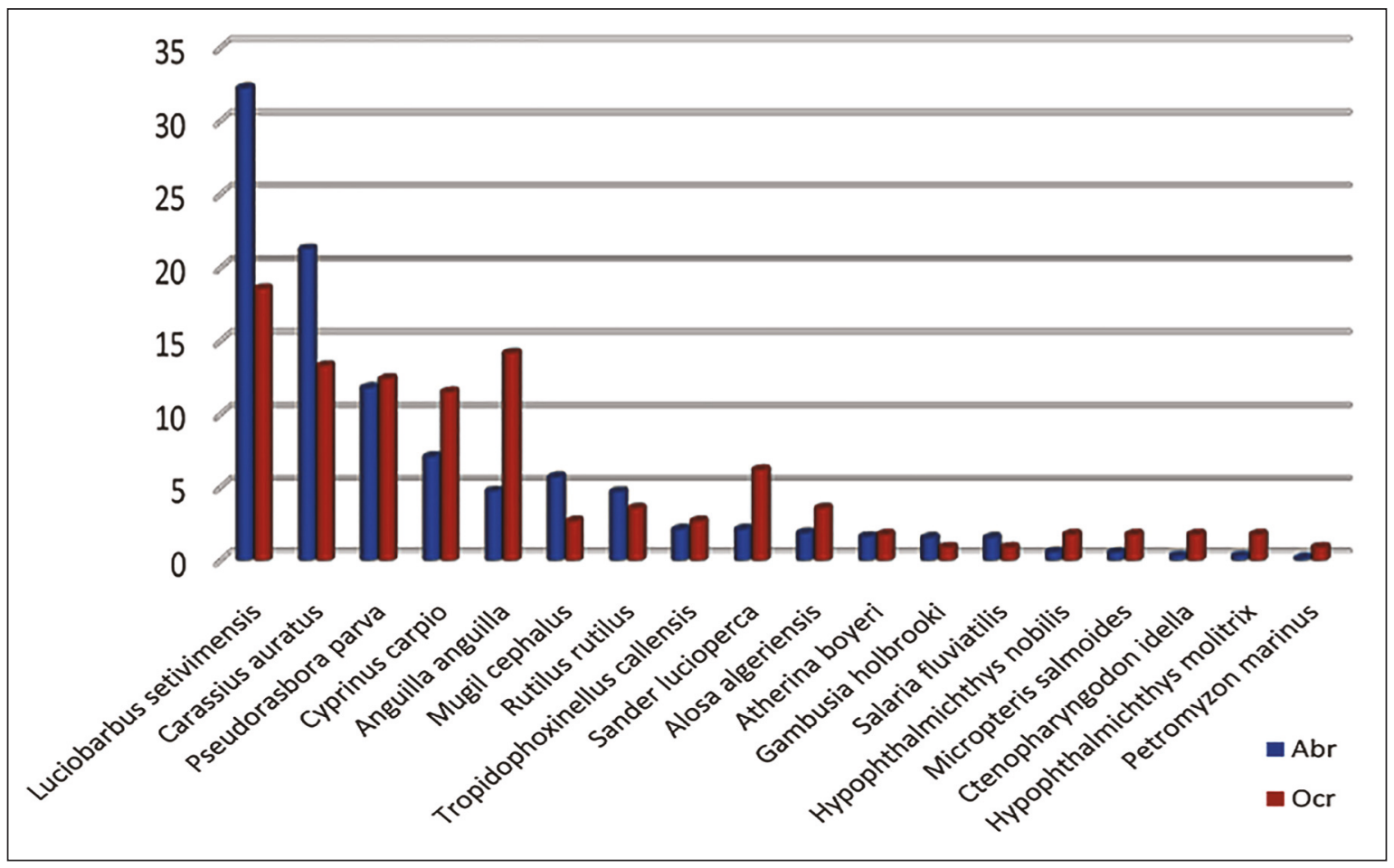

Figure 2. Relative abundance and occurrence of freshwater fish sampled in West Kabylia. $\mathrm{Abr}=$ Relative abundance over all sites; Ocr $=$ Frequency of occurrence over all sites.

introduced within the framework of national programs aimed at restocking water bodies for aquaculture, reducing eutrophication in reservoirs, and control of mosquito populations.

\section{Species accounts}

\section{Family PETROMYZONTIDAE}

\section{Petromyzon marinus (Linùnaeus, 1758)}

This anadromous species is rarely found in Algerian rivers (Lounaci-Daoudi et al, 2016). It cannot be excluded that it resides in western Kabylia. The only previous record in the area is from 2016, upstream of the Taksebt dam.

Recorded from site: 12 (Fig. 1).

\section{Family ANGUILLIDAE}

\section{Anguilla anguilla (Linnaeus, 1758)}

Inhabits diverse lacustrine and fluvial habitats throughout the study area and was recorded in all four reservoirs within the Sebaou drainage (Taksebt, Djebla, Ain Zaouia, and Draa El Mizan), plus stretches of the main stem and major tributaries. This species is adversely affected by dam construction, which interferes with its migration routes. It is routinely stocked in reservoirs throughout West Kabylia, but was not recorded at Cap-Djinet during this study despite glass eels being regularly introduced there.

Recorded from sites: 1, 2, 3, 4, 5, 6, 7, 10, 19, 20, 21, 23, 24, 25, 26, 29 (Fig. 1).

\section{Family CLUPEIIDAE}

\section{Alosa algeriensis (Regan, 1916)}

This species might be widespread along the Mediterranean coast of North Africa and was recently recorded from Takdemt. It potentially spawns in the Sebaou River.

Recorded from sites: 1, 4, 21, 23 (Fig. 1).

\section{Family CYPRINIDAE}

\section{Cyprinus carpio (Linnaeus, 1758)}

Widely recorded from reservoirs and downstream river stretches throughout the Sebaou drainage. It was originally imported for aquaculture 


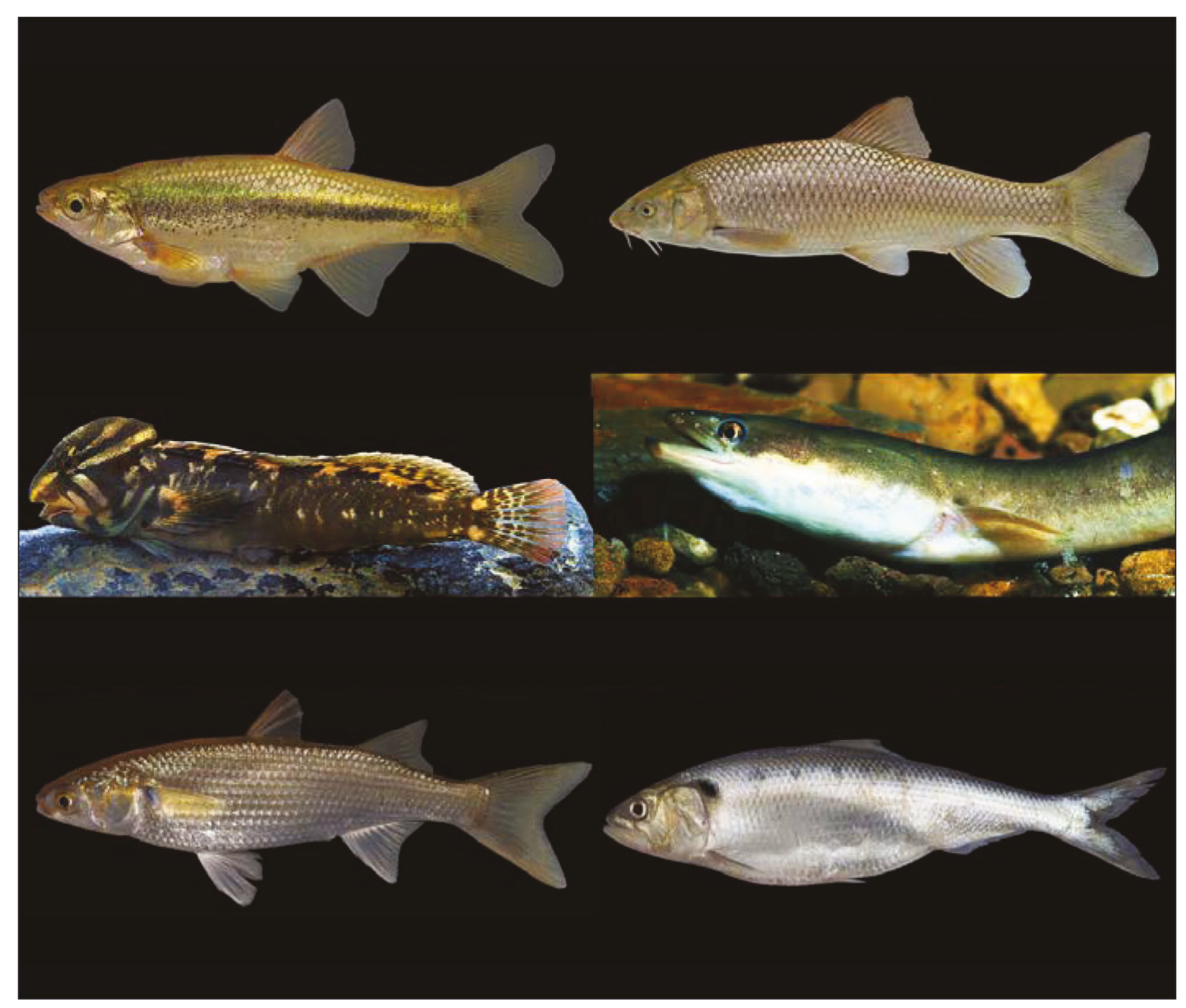

Figure 3. Examples of native species collected during this study. Anticlockwise from top left: Tropidophoxinellus callensis, Soummam River, Algeria; Salaria fluviatilis, Oued Boughzazene, Algeria; Mugil cephalus, Atlantic coast; Morocco; Right from top: Luciobarbus setivimensis, Soummam River, Algeria; Anguilla anguilla, Rhine River, Germany; Alosa algeriensis, Soummam River, Algeria.

but self-sustaining populations now exist across northern Algeria.

Recorded from sites: 3, 4, 5, 6, 8, 9, 10, 19, 20, $23,24,25,26$.

\section{Luciobarbus setivimensis (Valenciennes, 1842)}

The most ubiquitous native freshwater fish species in West Kabylia. It is present throughout middle and upper parts of the Sebaou drainage, including the three major tributaries and all artificial lakes. Often the only species present in headwater streams, but absent in the lower Sebaou.

Recorded from sites: 6, 7, 8, 11, 12, 13, 14, 15, $16,17,18,20,21,22,23,24,25,26,28,29$.

\section{Carassius auratus (Linnaeus, 1758)}

Present throughout the Sebaou drainage, including all three major tributaries and the Taksebt and Djebla reservoirs.

Recorded from sites: 2, 3, 4, 5, 6, 9, 10, 11, 12 , 13, 20, 21, 22, 23, 24 (Fig. 1).

\section{Family XENOCYPRIDIDAE}

\section{Ctenopharyngodon idella (Valenciennes, 1844)}

Recorded from the Taksebt and Ain Zaouia reservoirs during the present study. It does not reproduce naturally in northern Algeria but continues to 


\begin{tabular}{|c|c|c|c|c|c|c|c|}
\hline $\begin{array}{l}\text { Map } \\
\text { code }\end{array}$ & City & Drainage & Sub-drainage & Site & $\begin{array}{l}\text { Description } \\
\text { of site }\end{array}$ & Latitude & Longitude \\
\hline 1 & Boumerdes & Sebaou & Lower Sebaou & Takdemt & River & 36.910108 & 3.853730 \\
\hline 2 & Boumerdes & Sebaou & Lower Sebaou & Baghlia & River & 36.833142 & 3.867943 \\
\hline 3 & Tizi Ozou & Sebaou & Middle Sebaou & Tadmait & River & 36.752775 & 3.935065 \\
\hline 4 & Tizi Ozou & Sebaou & Middle Sebaou & Dbk & River & 36.747557 & 3.993603 \\
\hline 5 & Tizi Ozou & Sebaou & Bougdoura & Bougdoura & River & 36.690806 & 3.941464 \\
\hline 6 & Tizi Ozou & Sebaou & Bougdoura & Assif Boghni & River & 36.636556 & 3.924423 \\
\hline 7 & Tizi Ozou & Sebaou & Bougdoura & Ath Kouffi & River & 36.478192 & 3.961580 \\
\hline 8 & Tizi Ozou & Sebaou & Middle Sebaou & Tazmalt & River & 36.716304 & 4.098301 \\
\hline 9 & Tizi Ozou & Sebaou & Aissi & Taksebt 1 & Reservoir & 36.675616 & 4.119193 \\
\hline 10 & Tizi Ozou & Sebaou & Aissi & Taksebt 2 & Reservoir & 36.660559 & 4.128693 \\
\hline 11 & Tizi Ozou & Sebaou & Aissi & Taksebt 3 & Reservoir & 36.620172 & 4.139169 \\
\hline 12 & Tizi Ozou & Sebaou & Aissi & Takhoukht & River & 36.609769 & 4.151970 \\
\hline 13 & Tizi Ozou & Sebaou & Aissi & Pont Takhokht & River & 36.590573 & 4.155173 \\
\hline 14 & Tizi Ozou & Sebaou & Aissi & \begin{tabular}{|l|} 
Route \\
Ouadhias \\
\end{tabular} & River & 36.588679 & 4.151970 \\
\hline 15 & Tizi Ozou & Sebaou & Aissi & Assif Tamda & River & 36.551293 & 4.137081 \\
\hline 16 & Tizi Ozou & Sebaou & Aissi & \begin{tabular}{|l|} 
Tamda \\
oussarghi
\end{tabular} & River & 36.517778 & 4.100636 \\
\hline 17 & Tizi Ozou & Sebaou & Aissi & Assif larbba & River & 36.567359 & 4.169997 \\
\hline 18 & Tizi Ozou & Sebaou & Aissi & Assif djamaa & River & 36.543715 & 4.281334 \\
\hline 19 & Tizi Ozou & Sebaou & Upper Sebaou & Tamda & River & 36.703927 & 4.191311 \\
\hline 20 & Tizi Ozou & Sebaou & Upper Sebaou & Chaib & River & 36.712649 & 4.221759 \\
\hline 21 & Tizi Ozou & Sebaou & Upper Sebaou & Freha & River & 36.718871 & 4.342246 \\
\hline 22 & Tizi Ozou & Sebaou & Boubhir & Boubhir 1 & River & 36.658516 & 4.379244 \\
\hline 23 & Tizi Ozou & Sebaou & Boubhir & Boubhir 2 & River & 36.640532 & 4.386606 \\
\hline 24 & Tizi Ozou & Sebaou & Middle Sebaou & Djebla & Reservoir & 36.777804 & 4.207914 \\
\hline 25 & Tizi Ozou & Sebaou & Bougdoura & $\operatorname{Ain} Z$ & Reservoir & 36.534604 & 3.867464 \\
\hline 26 & Tizi Ozou & Sebaou & Bougdoura & D-mizan & Reservoir & 36.565379 & 3.841095 \\
\hline 27 & Tizi Ozou & Sebaou & Lower Sebaou & Cap-Djinet & Reservoir & 36.864814 & 3.776847 \\
\hline 28 & Tizi Ozou & Sebaou & Boubhir & Sahel & Reservoir & 36.589422 & 4.459776 \\
\hline 29 & Tizi Ozou & Sidi Khlifa & N/A & N/A & River & 36.881668 & 4.509135 \\
\hline 30 & Tizi Ozou & Ath Chaffa & N/A & N/A & River & 36.884132 & 4.537978 \\
\hline
\end{tabular}

Table 2. Details of sites sampled during this study. 
be widely stocked (Kara, 2011). It is native to Eastern Asia, and fry were first introduced to Algeria from Hungary during the mid-1980s for aquaculture and control of aquatic vegetation (Chaibi, 2014).

Recorded from sites: 10, 25 (Fig. 1).

Hypophthalmichthys molitrix (Valenciennes, 1844)

Recorded only in Taksebt reservoir during the present study. Native to Eastern Asia and was introduced to many artificial lakes in Algeria during the mid-1980s for aquaculture purposes, but does not reproduce naturally (Chaibi, 2014). It first appeared in Taksebt just after the dam was completed in 2002 (Kara, 2011)

Recorded from sites: 9, 10 (Fig. 1).

Hypophthalmichthys nobilis (Richardson, 1845)

Recorded only in Taksebt reservoir during the present study. Native to central and southern China, Algerian populations do not reproduce naturally and are the result of stocking (Chaibi, 2014). This species was first introduced to the country during the mid-1980s (Kara, 2011).

Recorded from sites: 9, 10 (Fig. 1).

\section{Family GOBIONIDAE}

Pseudorasbora parva (Temminck et Schlegel, 1846)

Recorded from the Sebaou River drainage for the first time during the present study, where it was among the most common and abundant species. It is present in Taksebt reservoir, the Sebaou main channel and the lower parts of all three major tributaries, where juveniles were also observed. This species was unintentionally introduced to northern Algeria alongside other species imported for aquaculture.

Previous studies mentioned that it is present but isolated in the region, but it is becoming more widespread (Kara, 2011).

Recorded from sites: 2, 3,4,5,6, 9, 10, 11, 12, 13, 14, 17, 21, 23 (Fig. 1).

\section{Family LEUCISCIDAE}

\section{Rutilus rutilus (Linnaeus, 1758)}

Recorded from the Taksebt reservoir and Aïssa River just above the artificial lake. This species was probably introduced from Europe to Algeria accidentally alongside other species imported for aquaculture.

Recorded from sites: 10, 11, 12, 27 (Fig. 1).

\section{Tropidophoxinellus callensis (Guichenot, 1850)}

Recorded from two artificial lakes during this study. It has been previously misidentified as $\mathrm{Al}$ burnus alburnus (Lounaci-Daoudi et al., 2016). This species was possibly introduced to West Kabylia, where it is also known from the Soummam River (Bacha \& Amara, 2007), but further study is required to confirm this hypothesis.

Recorded from sites: 10, 12, 27 (Fig. 1).

\section{Family ATHERINIDAE}

Atherina boyeri (Risso, 1810)

This coastal species is here reported for the first time from the Taksebt reservoir. It is likely to be a recent and possibly accidental introduction.

Recorded from site: 10 (Fig. 1).

Family POECILIIDAE

Gambusia holbrooki (Girarad, 1959)

The eastern mosquitofish was recorded from Cap Djinet reservoir for the first time during this study. This species is native to the eastern United States, and was introduced to Algeria in 1926 (Kara, 2011).

Recorded from sites: 27 (Fig. 1).

\section{Family MUGILIDAE}

\section{Mugil cephalus (Linnaeus, 1758)}

This mullet was common in the lower Sebaou and Sidi Khlifa rivers, where juveniles were also observed. Fingerlings are regularly introduced to Cap Djinet reservoir where they are left to grow on before being fished for subsistence.

Recorded from sites: 1, 27, 29 (Fig. 1).

\section{Family BLENNIIDAE}

\section{Salaria fluviatilis (Asso, 1801)}

This species has a very restricted range in Algeria. Its distribution extends eastwards from the Ait Chaffa River, where it was recorded for the first 
time during this study, to the Agrioun River draining to the Gulf of Béjaiia. Additional field surveys are required to establish the limits of its range with certainty.

Recorded from site: 30 (Fig. 1).

\section{Family CENTRACHIDAE}

Micropterus salmoides (Lacépède, 1802)

This species is confined to artificial lakes within the study area. It is native to North America from where it was introduced to Algeria for angling during the 1950s (Moreau et al., 1994; Kara, 2011). It is present in central and western parts of the country (Bacha \& Amara, 2007) and has been reported from West Kabylia since the mid-1980s, when it was stocked as part of a national government fisheries program (Kara, 2011).

Recorded from sites: 26, 27 (Fig. 1).

\section{Family PERCIDAE}

\section{Sander lucioperca (Linnaeus, 1758)}

Recorded from Cap Djinet reservoir for the first time during this study. It is also present in the Draa El Mizan and Taksebt reservoirs, and the Aïssi River above the latter. The populations in Taksebt and Cap Djinet appear to be self-sustaining, with juveniles observed. This species was introduced to Algeria from Hungary during the mid-1980s for aquaculture (Kara, 2011).

\section{DISCUSSION}

This study provides the first comprehensive inventory of freshwater fishes inhabiting the West Kabylia region, and contributes baseline data for potential management and monitoring programs. As is typical across Algeria, the native freshwater fish fauna is depauperate and today dominated by alien species.

With 18 taxa recorded, freshwater fish species richness in West Kabylia is comparable with other regions in northern Algeria, such as the Soummam drainage with 19 species (Bachat \& Amara, 2007), the Aurès with 14 species (Chaibi, 2014), and the upper Chéliff reservoirs with 10 species (Djezzar, 2015).
Non-native species represented $61 \%$ of total richness, and several have established self-sustaining populations. If euryhaline, native species are excluded, non-native species comprise $79 \%$ of the regional ichthyofauna. The most common and widespread non-natives were Carassius auratus and Pseudorasbora parva, which were more widespread than all native species other than Luciobarbus setivimensis. The establishment of non-native species is likely to have been favoured by the construction of dams and the artificial lakes they create, with a subsequent homogenization of resident fish communities (Clavero \& Hermoso, 2011; Liew et al., 2016). For example, in Taksebt (the largest reservoir within the Sebaou drainage) we recorded 12 alien species among which just three were native and only one, Luciobarbus setivimensis, was a primary freshwater resident.

Throughout the study area, there is no data regarding the current status of native fish species population trends, the timing of non-native fish species introductions, or their likely repercussions on native ecosystems and biodiversity. This study, therefore, provides an initial baseline for implementation of a monitoring program that should include additional field studies designed to fill these knowledge gaps in order to facilitate informed future management.

\section{ACKNOWLEDGEMENTS}

The work is part of the "Continental Aquatic Ecosystems Research' project initiated by the natural resources laboratory of Mouloud Mammeri University in Tizi Ouzou. We would like to thank colleagues and local fishermen for their kind assistance during sampling. The authors would like to thank the editor and the two anonymous reviewers for their constructive comments on the manuscript.

\section{REFERENCES}

Almaça C., 1969. Révision critique de quelques types de Cyprinidae d'Europe et d'Afrique du Nord des collections du Muséum National d'Histoire Naturelle de Paris. Bulletin du Muséum National d'Histoire Naturelle de Paris, 40 (6): 1116-1144.

Azeroual A. 2003. Monographie des poissons des eaux continentales du Maroc: systématique, distribution et écologie. Thèse de Doctorat, Université Mohammed V-Agdal, Rabat, 193 pp. 
Bacha M. \& R. Amara. 2007. Les poissons des eaux continentales d'Algérie. Étude de l'ichtyofaune de la Soummam. Cybium, 31: 351-358.

Blanco JL., T. Hrbek \& I. Doadrio. 2006. A new species of the genus Aphanius (Nardo, 1832) (Actinopterygii, Cyprinodontidae) from Algeria. Zootaxa, 1158: 39-53. https://doi.org/10.11646/zootaxa.1158.1.2

Bouhadad R. 1993. Distribution des espèces de genre Barbus en Algérie. Cahier Entomologique, 13: 185188.

Bouhadad R. \& B. Asselah. 1998. Biodiversité comparée de l'ichtyofaune des eaux douces algériennes (Sahara et nord) et maghrébine. Santé plus, 61: 19-22.

Boulenger G.A., 1911. Catalogue of the freshwater fishes of Africa in the British Museum, London, 2: 529.

Brahimi A., Freyhof J., Henrard A. \& Libois R., 2017. Luciobarbus mascarensis and Luciobarbus chelifensis (Cyprinidae): two new species in Algeria. Zootaxa, 4277: 32-50. https://doi.org/10.11646/zootaxa.4277.1.3

Brahimi A., Libois R., Henrard A. \& Freyhof J., 2018. Luciobarbus lanigarensis and L. numidiensis, two new species of barbels from the Mediterranean Sea basin in North Africa (Teostei: Cyprinidae). Zootaxa, 4433: 542-560. https://doi.org/10.11646/zootaxa.4433.3.9

Chaoui L., Kara M.H., Faure H.E. \& Quignard J.P., 2006. L'ichtyofaune de la lagune du Mellah (Algérie Nord Est): Diversité, production et analyse des captures commerciales. Cybium, 30: 123-132.

Chaibi R., 2014. Connaissance de l'ichtyofaune des eaux continentales de la région des Aurès et du Sahara Septentrional avec sa mise en valeur. Thèse de Doctorat Es sciences, Université de Biskra, Algérie, 237 pp.

Clavero M. \& Hermoso V., 2011. Reservoirs promote the taxonomic homogenization of fish communities within river basins. Biodiversity and Conservation, 20: 41-57. https://doi.org/10.1007/s10531-010-9945-3

Dieuzeide R., 1927. L'oued Réghaia. Bulletin de la station d'aquaculture et de pêche de Castiglione, 2: 161-171.

Dieuzeide R., 1932. L'empoissonnement des eaux de l'oued Mazafran. Bulletin de la station d'aquaculture et de pêche de Castiglione, 2: 189-207.

Dieuzeide R. \& Champagne R., 1950. L'able de la calle (Phoxinellus callensis Guichenot). Bulletin de la station d'aquaculture et de pêche de Castiglione, 2: 9-28.

Dieuzeide R. \& Roland J., 1951. Le laboratoire d'hydrobiologie et de pisciculture d'eau douce du Mazafran. Bulletin de la station d'aquaculture et de pêche de Castiglione, 3: 190-207.

Djezzar M., 2015. Biodiversité et diagnose piscicole de trois lacs de barrages du haut Chellif (Ain Defla, Algérie): Ghrib, Harreza et Sidi M'Hamed Bentaiba.
Thèse de Doctorat Es Sciences. ENS Agronomique d'El Harrach, Alger.

Doadrio I., 1994. Fresh water fish fauna of North Africa and its biogeography. Annales du Musée Royal d'Afrique Centrale, Zoologie, 275: 21-34.

Doadrio I., Bouhadad R. \& Machordom A., 1998. Genetic differentiation and biogeography in Sahara populations of the genus Barbus (Osteichthyens, Cyprinidae). Folia Zoologica, 47: 7-20.

Ford M., Brahimi A., Baikeche L., Bergner L., Clavero M., Doadrio I., Lopes-Lima M., Perea S., Yahyaoui A. \& Freyhof J., 2020. Freshwater fish distribution in the Maghreb: a call to contribute. OSF Preprints, January 9. https://doi.org/10.31219/osf.io/kx4gc.

Jeannel R., 1956. Un nouveau genre de Psélaphides de l'Ile Maurice (Col.). Mauritius Institute Bulletin, 3: 279-282.

Kara H.M., 2011. Freshwater fish diversity in Algeria with emphasis on alien species. European Journal of Wildlife Research, 58: 243-253. https://doi.org/10.1007/s10344-011-0570-6

Kottelat M. \& Freyhof J., 2007. Handbook of European freshwater fishes. Cornol, Switzerland, Publications Kottelat. i-xiii +646 pp.

Lehner B., Verdin K. \& Jarvis A., 2008. New global hydrography derived from space borne elevation data. Eos, Transactions, AGU, 89: 93-94.

Lévêque C. \& Paugy D., 2006. Distribution géographique et affinités des poissons d'eau douce africains. In: Lévêque C. \& Paugy D. (Eds.), Les poissons des eaux continentals, pp. 59-74. Diversité, écologie, utilisation par l'homme, Editions IRD, Paris, 521 pp.

Liew J.H., Tan H.H. \& Yeo D.C., 2016. Dammed rivers: impoundments facilitate fish invasions. Freshwater Biology, 61: 1421-1429.

Lounaci A., 2005. Recherches sur la faunistique, l'écologie et la biogéographie des macroinvertébrés des cours d'eau de Kabylie (Tizi-Ouzou, Algérie). Thèse de Doctorat, Université de Tizi-Ouzou, Algérie, $280 \mathrm{pp}$.

Lounaci-Daoudi D., Lounaci A. \& Arab A., 2016. Freshwater fish fauna of Algeria: the fish fauna of inland waters of Great-Kabylia. Advances in Environmental Biology, 10: 74-84.

Lounaci A. \& Vinçon G., 2005. Les Plécoptères de la Kabylie du Djurdjura (Algérie) et biogéographie des espèces d'Afrique du Nord [Plecoptera]. Ephemera, 6: 109-124.

Moreau J., Arrignon J. \& Jubb R.A., 1994. Introduction of foreign fishes in African inlands waters. Suitability and problems. In: Lévêque C., Bruton M.N. \& Sentongo G.W. (Eds.), Biology and ecology of African freshwater fishes, ORSTOM: 395-426.

Pellegrin J., 1921. Les poissons des eaux douces de l'Afrique du Nord française: Maroc, Algérie, Tunisie, Sahara. Mémoire Société Sciences Naturelles du Maroc, 1: 1-216. 
Penczak T. \& Moliński M., 1984. Fish production in Oued Sebaou, a seasonal river in North Algeria. Journal of Fish Biology, 25: 723-732.

Roberts T.R., 1975. Geographical distribution of African freshwater fishes. Zoological Journal of the Linnean Society, 57: 249-319.

Rosenbaum G., Lister G.S. \& Duboz C., 2002. Reconstruction of the tectonic evolution of the western Mediterranean since the Oligocene. In: Rosenbaum G. \& Lister G.S., Reconstruction of the evolution of the Alpine-Himalayan Orogen. Journal of the virtual explorer, 8: 107-130. https://doi.org/10.3809/jvirtex.2002.00053

Seurat L.G., 1922. Les connaissances actuelles sur les poissons culicivores. Bulletin de la station d'aquaculture et de pêche de Castiglione, 1: 55-73.

Seurat L.G., 1930. Exploration zoologique de l'Algérie de 1830 à 1930. Collection du centenaire de l'Algérie. Masson et Cie Editeurs, Paris.

Zouakh D.E., Bouhadad R., Moulla M. \& Cherbi M., 2004. Ichtyofaune, macrofaune benthique et peuplement zooplanctonique des hydrosystèmes du Hoggar et du Tassili. Bulletin de la société zoologique de France, 103: 55-80. 
